\section{Tom Odhiambo}

Tom Odhiambo is an Associate researcher at the Wits Institute for

Social and Economic Research, University of the Witwatersrand,

Johannesburg.

Email: todhiambo@hotmail.com

\section{Juvenile delinquency and violence in the fiction of three Kenyan writers}

\title{
Juvenile delinquency and violence in the fiction of three Kenyan writers
}

This essay is a preliminary examination of crime and violence in postcolonial Kenyan fiction. It examines how three Kenyan writers have dealt with the themes of crime and violence in their fiction. Through examination of the fiction of John Kiriamiti, Meja Mwangi and John Kigia, the paper postulates that the prevalence of juvenile delinquents in this fiction and the related acts of violence and criminality could be read as indicators of the failure of the postcolonial Kenyan state to "include" these young men (and women) into the mainstream of society. The essay further argues that there is a correlation between marginalisation of the youth in society and their adoption of anti-social behaviour as strategies to access material resources. Key words: Juvenile delinquency, Kenyan fiction, violence, postcolonial Africa.

\section{Introduction}

Juvenile delinquency and violence are some of the common themes in postcolonial Kenyan literature that is set in the 1970s, 1980s into the 1990s. This prevalence of crime and violence in this fiction parallels a history of crime and violence that is generally attributed to youth in postcolonial Africa. Social reality in Africa after colonialism is characterized by violence according to a number of scholars of the continent (Mbembe 2001, Bayart 1993, Chabal and Daloz 1991). These scholars suggest that the many coups in the post-independence era, military dictators and autocratic rulers, civil wars, the collapse of economies and the consequent cases of grand-scale corruption, and internal state of anarchy in many countries in Africa in the period following independence account for Africa's troubles. In this political and social chaos, youths have been implicated either as victims or perpetrators in some form or another given that some estimates suggest that they make up $80 \%$ of the continent's population (see Niebuhr 2002). This social category is most affected by declining standards of living, diminishing possibilities of employment and therefore a life defined by poverty. It is inevitable that the many unemployed young men and women added to the rising numbers of the urban poor and disadvantaged resort to crime and violence as a means of accessing material goods. Commenting on the status of the youth in Africa, Filip De Boeck and Alcinda Honwana (2005: 1) write: " [...] children and youth are often placed at 
the margins of the public sphere and major political, socio-economic, and cultural processes. The challenging situation on the continent makes young people particularly vulnerable." When economies are weak and unable to serve the needs of the citizenry; when a nation-state experiences poor governance; or even when faced with invasive forces of globalization, the youth suffer most.

Although Kenya enjoyed a period of "seeming" economic prosperity, and social and political stability in the immediate post-independence period, the economy was severely jolted by the world economic recession of the 1970s. One of the consequences of the worsening socio-economic conditions in the country at the time was the rise in unemployment, especially among the youth. Inevitably some of them drifted into delinquency, committing minor crimes and eventually graduating into adult criminals. These delinquents and young criminals are the characters found in the fiction that I analyze in this essay. The fiction in question is set in the Kenya of the 1970s, mostly in the city of Nairobi because of its economic, political, social and cultural significance. Like any major African city such as Johannesburg, Lagos, Dar es Salaam, Kinshasa, or Accra, Nairobi provides a natural backdrop for most Kenyan writers because it is where most young men and women emigrate to in search of opportunities for self-improvement. Their experiences of the complexities and hardships of modern city life are in themselves stories of social reality of postcolonial societies. The novels that I analyze in this essay are in a sense a distillate of these experiences but they do also offer a critique of the postcolonial Kenyan society that continues to marginalize and exclude young people from socio-economic opportunities and resources. For instance, a causal if not a natural link between unemployment and criminality is suggested in this literature. The narrative voices in the novels seem to imply that the transition from juvenile delinquency and criminal behaviour of the youth to the hard-core adult criminals portrayed in the fiction is due to the society's inability to provide opportunities for socio-economic advancement for the youth and also because of inequitable distribution of wealth and economic resources.

I focus my attention on three texts Kill Me Quick (1973) by Meja Mwangi; My Life in Crime (1984) by John Kiriamiti; and John Kigia Kimani's Life and Times of a Bank Robber (1989). The three are examples of novels in independent Kenya that specifically address themselves to the subject of juvenile criminality and violence. However I also make references to Son of Fate (1994) and the Sinister Trophy (1999) also by John Kiriamiti. The reading of these texts is an attempt to locate the crime and violence in the fiction within the transitional Kenyan urban social and economic landscapes in the post-independence period in which a majority of social actors are deprived of means of earning a livelihood. I suggest that this fiction seeks to dramatize the relationship between crime and violence in Kenya and the state's institutional incapacity to render both justice and equitable distribution of economic resources to its citizens. Thus the violence depicted in these novels does not merely have as its ends the desire to access 
material goods but it is also deployed as a challenge to the regimes of law and order and the authority of the state. It goes beyond mere protest by a marginalized group to suggest an attempt by socio-economically deprived and disadvantaged young men and women to re-assert themselves within the structures of social and economic privilege in Kenya.

\section{The state and the youth in postcolonial Africa}

Jean-François Bayart (1993) characterizes the postcolonial African socio-economic and political orders as potentially self-destructive. He notes the significant link between the socio-economic and political spheres of life in Africa and argues that there is an important element of interdependence between the two. This connection is based on the forces that determine the creation of wealth, the exploitation of economic resources, the distribution of that wealth within the society, the networks of social relationships and the nature of various political and government institutions among others. Bayart suggests that the institutions, systems and networks that control and determine the distribution of economic resources and wealth within the postcolony are generally flawed if not completely dysfunctional. As a result of the inability of the system to sustain a coherent mechanism for fair and equitable division of national resources different individuals or interest groups that have been pushed onto the margins of the formal systems of resource distribution resort to strategies outside the officially sanctioned means of accessing economic resources or livelihood to make a living. Consequently the government's authority, the force of the law and the authority of institutions that safeguard it are challenged in an environment that increasingly becomes criminalized.

Because of the institutionalized absence of fairness in sharing and distributing wealth, much of the national economic resources are controlled by or concentrated in the hands of a few, what Bayart terms the "big men". The majority of the society remains outside the institutional networks, which are almost exclusive to the "big men" [and women], and therefore has to fend for themselves by other means. In Bayart's analysis, a majority of the youth in postcolonial Africa are located in the second category. Because of their age, the generational difference and lack of or limited contacts in the networks of socio-economically powerful groups, the youth rank quite low in the hierarchy of persons who have access to wealth and resources in modern Africa. In a subtitle of one of his chapters, which paraphrases a Cameroonian proverb "Goats eat where they are tethered", Bayart (1993: 235) invokes a powerful metaphor of the consumptive impulses that determine the relationship between the African politician or bureaucrat and public wealth. Although Bayart is interested in the embezzlement and misappropriation of public resources by those entrusted with it and the complicity of other members of the society in the so-called "politics of the 
belly," what is relevant to this discussion is his formulation of the struggles waged by different social groups over public wealth. In characterizing the "youth" as engaged in the struggle to stake a claim to public wealth, Bayart writes:

In many ways the juvenile underworld has succeeded where the peasant revolts and trade-union marches have failed. In many of the metropolitan areas of the continent, it has installed a veritable balance of terror and has left the rich with little choice but to resort to the systematic use of violence. Hunted by a merciless police force - if the police are not their accomplices - and subject to the harsh law of the lynch mob, the young thieves have no choice but "to kill or be killed". Their numbers are nevertheless on the increase. Statistics show that banditry has become one of the principal "popular modes of political action" in Africa south of the Sahara if one accepts that the enunciative procedures of the State are primarily related to the distribution of wealth. (Bayart 1993: 240-241)

To illustrate further his claim Bayart (1993: 241) cites a situation where juvenile criminals have become a potent force that poses a threat to national security, "As one of the elder statesmen of the Cameroonian regime admitted in 1971: 'we could mobilize the entire army under our command but we still couldn't arrest all the young criminals [...] because criminals outnumber our forces of law and order.'”

Bayart (1993: 241) seems to emphasize the point that juvenile delinquency and criminality among the youth goes beyond mere transgression of the law and the committing of misdemeanour. Indeed there are pressing social and economic needs and desires by these young men and women which have to be satisfied, whatever the means available to them. If to break the law is the only way to get money to buy food and clothing and rent a room, so be it, these young men and women would seem to reason. However, Bayart (1993: 241) cautions that engagement in economic crime is not necessarily a marker of marginalization. But I wish to emphasize that so long as the African youth remain excluded from the economic spheres of their societies, marginalized from the chains of distribution of national wealth and continue to live in a general state of indeterminacy they will remain a potent force for social and political instability.

\section{Socio-economic character of independent Kenya}

Colin Leys' (1978) study of underdevelopment in Kenya provides a critical analysis of social and economic life after independence. Works by scholars of Kenyan history such as Bruce Berman (1990) and Berman and John Lonsdale (1992) further emphasize his argument. Leys traces the emergence of the bourgeois class in Kenya from the immediate post-independence period when economic resources and property, mostly large commercial agricultural farms, exchanged ownership from European settlers 
to Africans and other commercial and industrial property was partially transferred from Asians to Africans. The process of economic empowerment of the majority African population was accelerated when the nationalization of property and Africanization - a process akin to Black Economic Empowerment in South Africa - of both the public service and private sectors of the economy were implemented in the late 1960s. Although the colonial government had already initiated some transfer of land to Africans from around 1959 when it became apparent that independence would soon have to be granted to the African population, it is only after independence, with a majority African representatives in the legislature, that what had been the rhetoric of the anti-colonial struggle which demanded land restitution and economic empowerment of African Kenyans became law beginning with the Trade Licensing Act of 1967 (Ochieng'1995: 85). This legislation barred non-citizens from trading in rural and non-urban areas and specified a list of goods which could only be traded by citizen (Ochieng'1995: 85). The anticipated net effect of these policies was to redress the socio-economic inequalities created by the colonial system. However, evidence suggests that it is only those individuals who could access finances who managed to share in and integrate in the new economy. As Europeans and Asians sold their businesses and industries and departed, the government bought some of these enterprises whilst the rest passed on to a few individuals within the "networks of proximity to the state" who were able to secure bank loans, guaranteed by the government. One of the consequences of this new economic order was the emergence of a new class of African businessmen and entrepreneurs which was, however, thinly spread nationally. This group of new "owners of means of productions and commerce" - the black capitalists and merchants - was also mainly based in the urban centres which had better developed infrastructure and means of communication, had financial and banking institutions and offered opportunities for further investment and growth.

However the new owners of property, in collaboration with politicians and government bureaucrats, succeeded at preserving their newly acquired privileges through predatory activities such as appropriation and theft of public property than by actually producing wealth. In subsequent years little or no wealth was produced and whatever wealth that was available was concentrated in the hands of a few individuals. Although the systematic accumulation of wealth within a small group of elites in Kenya began when Jomo Kenyatta ruled, it was continued in the time if his successor Daniel arap Moi when the mainly Kikuyu elite was replaced by a Kalenjin elite as David Throup (1987: 33-74) suggests. Such politics of displacement of one economic group and its replacement with another along narrow ethnic lines has resulted in the impoverishment of a majority of the population through unemployment and underemployment because economic resources are often directed into unproductive activities. Even for individuals who are gainfully employed the cost of living has generally outstripped their incomes. It is possible to speculate that one of the more insidious 
consequences of the politics of displacement during the Moi era was the pauperization of many members of the Kikuyu ethnic group, who had been key beneficiaries of the old order; and therefore the prevalence of criminal elements, in the literature under discussion, whose identity is Kikuyu, as their names suggest. However, it should be noted that the Kikuyu are the majority ethnic group in Kenya and make up a large percentage of the populations of urban Kenya.

To revert to the formulation of the "big man", in order to balance the socio-economic equation, the "others" who are left out of the "circle of opportunity" also resort to predatory tendencies either directed at their own class/group/community or at the "big man" (see Bayart 1993: 76-78). In other words, the kind of social relationships that characterize such a society can be summed in the maxims "eat or be eaten", "kill or be killed", as Bayart reminds us of the philosophical basis of the violence perpetrated by the masses of youth criminals in contemporary Africa. The rise of juvenile delinquents or the "urban bandits" that Bayart talks of is an inevitable eventuality in postcolonial Africa unless the state radically revises its social, political and economic policies relating to the youth.

\section{Youthful delinquents}

Lars Johansson (1992: 33) characterizes Meja Mwangi's Kill Me Quick as a work that dramatises social acquiescence. Another critic has argued that the novel falls within the category of African literature that dramatizes disillusionment with the postcolonial condition and which "give expression to a profound rejection of African societies as they are presently constituted" (Kehinde 2004). Johansson's conclusions derive from a reading of the narrative techniques in Kill Me Quick and how the text articulates the ideology of the characters, the writer or the society. In her analysis, Kill Me Quick is a novel of resignation in which the characters, although conscious of their exploitation, do not seek to fundamentally alter their status:

Kill Me Quick is the novel in Mwangi's Nairobi triad that is most conspicuously permeated with acquiescence in the social formation of its setting. Acquiescence is here understood as a form of repression. To accept without protest or comment is to put a stop to discussion and dialogue and hence to the possibility of examining a current problematic. (Johansson (1992: 33)

Indeed in the title of the novel, which is picked from the last line of the poem prefacing the book, a state of resignation to the impending fate of the narrator or protagonist is suggested. The poem reads: 
Days run out for me,

Life goes from bad to worse,

Very soon, very much soon,

Time will lead me to the end.

Very well. So be it.

But one thing I beg of you.

If the sun must set for me,

If all must come to an end,

If you must be rid of me,

The way you have done with all my friends,

If you must kill me,

Do so fast.

KILL ME QUICK. (Mwangi 2001: vii)

Johansson's analysis of the novel, however, only provides one reading of Kill Me Quick which, one would grant, is partially correct. Meja and his friend Maina's actions lead to a capitulation to the dictates of the state and its institutions for enforcing compliance with the law: the police and the prisons. But not before they attempt to circumvent the laws that determine their access to material needs and wealth. Maina and Meja scavenge for food in the dustbins on the main streets of Nairobi and in its backstreets and have to be constantly alert in order to avoid arrest by policemen. Maina eventually decides to join and live with a gang of young criminals in "Shanty Land" - a slum. His actions represent a progression in the lives of these two young men from a state of deprivation of the basic physiological and physical needs which is though managed by efforts on their part to legitimately satisfy their needs to a state of desperation when they resort to "harmless violence" to find food. However, even the gang of young criminals in Shanty Land only uses violence as a means of persuasion, by threatening to harm one or inflict injury if the victim is not willing to part with his or her property. In most instances this group is made up only of what is socially and in the grammar of the judicial system known as "petty thieves" and pickpockets. At this stage in both the narrative and the lives of Meja, Maina and their friends, there exists only a nascent disregard of the law and the moral order - they only steal in order to satisfy the most basic of needs: food. However, the deplorable social and economic conditions which circumscribe the lives of these youthful criminals are juxtaposed with cases of affluence and material comfort enjoyed by a few individuals in the same society.

The signs of the demarcations between the poor and the rich in urban Kenya are clearly marked in Kill Me Quick. Shanty Land - representative of the sprawling slums characterizing urban housing in Nairobi such as Mathare, Kibera and Kaloleni - has its own laws and mechanisms of regulating social relationships which are not de- 
pendent on the broader judicio-legal system. This is the poor man's dominion. Shanty Land is not only removed from the backstreets of Nairobi where the underprivileged are supposed to stay according to Maina when he warns Meja, "[...] whatever you do, keep to the backstreets" (Mwangi 2001: 45), but it is also an emergent space for the poor with its own networks of relationships and social organization albeit full of insecurity and hopelessness. Ironically, in banter in the prison, when discussing the whereabouts of Maina one of the young criminals called Ngugi says, "I will tell you what. Maina has been elected his highness honourable mayor of Shanty Land" (Mwangi 2001: 148). The narrator goes on to describe the ensuing atmosphere amongst the group members after Ngugi's statement: "The others howled with laughter at the thought of Shanty Land being made a city. A city within a city. A city with a difference. And Maina of all the crooks in crookland being made the mayor" (Mwangi 2001: 148; emphasis added).

Thus the imagined construction of a specific identity, based on social and economic circumstances, away from the mainstream of economic, social, and political activities of the country, which have made these young men fringe social actors in the society, emerges. The urban bandits wish to have the power-social, economic and political - to determine their own destiny and even possess their own social spacegangland. Without any imaginable possibility of integrating into the mainstream of society, most of the young men and women are forced into crime and the use of violent means to access the basic needs of food, clothing and shelter but also to articulate their alienation. Early in the narrative, Maina narrates to Meja how circumstances had altered the fates of several of his friends:

"So", Maina went on, "all my friends became thieves and robbers. I would have done the same too but I was too cowardly to break into houses at night. I had not done much practice in running at school and could never trust my speed for getting away with purse snatching. So my friends went into the main streets and snatched purses and they are almost all of them in prison now, for one reason or another. Me, I turned into the backstreets and thrived. There isn't much competition for existence here, except with the mongrels and mongrels do not know how to open closed back doors. And the food is not all that bad if you allow for the smell, and such minor things." (Mwangi 2001: 2)

Yet in the end it is Maina who, enraged with having been disinherited and having realized that even the backstreets of Nairobi could not assure him of an undisturbed existence, commits murder and is condemned by the justice system to hang. When Meja, whilst in prison and having known of Maina's condition, wonders, "Why did this have to happen to him [Maina]? They say it is fate, but is it really? Is it?" (Mwangi 2001: 149), he clearly exhibits an understanding of the condition of many young people like him. In fact, in Meja's question, the author pre-empts an answer: No, it is 
not fate, because fate somehow refers to some power beyond the control of humans, something supernatural. Instead, it is the actions of men and women - or the society, which determine the vector of any individual's life. My conclusion here that Meja Mwangi hints at such a response is based on the thoughts of the protagonist, Meja, at night, in prison and lying on the bed previously occupied by Maina: "He turned over restlessly and lay on his back. The dim bulb up above he saw through clouds of tears. And instead of seeing the orange light, he saw the smiling face of his friend Maina saying, 'Somehow we have to live!'” (Mwangi 2001: 151)

It is this statement of triumph over the desperation of their lives that clearly shows that Kill Me Quick is a text that contains the seeds of internal textual subversion with the author presenting a picture of a chaotic world which remorselessly annihilates those like Maina and Meja who try to live by the moral expectations of the society even when they are deprived of the barest means of survival. It is those who heed Maina's words "somehow we have to live" and are daring enough to evolve new strategies for survival even if it is resorting to petty criminality who indeed may beat hunger or starvation and live to see another day. Such individuals, who are prepared to test the limits of the law and the moral order sanctioned by the state and the broader society, populate several novels including My Life in Crime, My Life with a Criminal or Life and Times of a Bank Robber, written several years after the publication of Kill Me Quick. There is a discernible narrative transition in these latter novels from the juvenile delinquents of Kill Me Quick to characters who seem to consciously choose a life of violent crime to earn a living.

\section{From "crimes of necessity" to crime as "lifestyle"}

The preface to My Life in Crime offers insight into the violent crimes that characterized Kenyan urban life in the 1960s and 1970s. It reads:

The late 1960s and early 1970s may be remembered as the years of the great bank and other armed robberies in Kenya. This is the true story of one of the participants in some of these robberies, John Kiriamiti. In raw and candid language he tells the story of how he dropped out of secondary school when he was only fifteen years old, and for a time became a novice pickpocket, before graduating into crimes like car-breaking and ultimately into violent robbery. This spell-binding story takes the reader into the underworld of crime, and it depicts graphically the criminal's struggle for survival against the forces of law. (Kiriamiti 1999a: I; emphasis added)

This preface draws attention to the main narrative by establishing the context of the story in My Life in Crime in claiming specificity for the criminal activities of the late 1960 s and the early 1970s. The rise in violent crimes that author alludes to above are referred to by John Kigia, whose confessional autobiography Life and Times of a Bank 
Robber, just like My Life in Crime, terms a robbery that happened in Nakuru town in Kenya on 9 February 1970 "historic", because it coincided with the a tour of lake Nakuru by the then president of Yugoslavia, Josef Broz Tito who was on a visit to Kenya. According to Kigia this robbery is "historic" because it was a daring act that embarrassed the Kenyan government. But there are two important points that link the two descriptions of crime above. The first has to do with the metamorphosis of the characters in the fiction from the "petty criminals" like Meja and Maina in Kill Me Quick into daring "hardcore criminals" who seem to operate within the boundaries of a different moral economy, one that actively transgresses the boundaries of law and order and the moral code. The second is the narrative strategy of using autobiography, particularly the self-confessional mode, to tell about the lives of criminals who consciously engage in violent crime.

The example of John Kiriamiti, alias Jack Zollo, illustrates the emergence of urban juvenile delinquency in Kenya, the rise of petty criminality and violent crime and the evolution of a culture of competing moral economies in the Kenyan society of the 1970s. Jack Zollo abandons school to live in Nairobi after being expelled from school for being the ringleader in a strike by fellow students. For some time he continues to pretend that he is attending school until his brother discovers that he was simply spending the money meant for school fees on tickets for films and alcohol. When he is confronted by his parents, he decides to escape from home to Nairobi. It is not take long before Kiriamiti is initiated into petty crime in Nairobi, after he falls victim to a trickster and loses all his possessions within three hours of arriving in the city (Kiriamiti 1999a: 7-9). The police to whom he appeals for assistance are not of much help. This is Kiriamiti's first lesson in the intricacies of town-life - that the law does not necessarily resolve everyone's problems. He exhausts his money after a few months and then desperation sets in. Luck comes his way when he witnesses a boy pick the pockets of a padre (Kiriamiti 1999a: 11). Within moments, Kiriamiti manages to intimidate the young pickpocket into sharing the loot with him. This is the beginning of his criminal life. He becomes an accomplished pickpocket and a popular figure in the criminal underworld of Nairobi. As he confesses, the progress is rapid from being a pickpocket to a car-breaker:

Within two years, that is between 1965 and 1967, I had become known to many criminals, from robbers, car breakers, shop breakers to car thieves and racketeers. I had also come to be known by the name Jack Zollo. I left the risky job picking pockets and joined car breakers. This was risky too but not half as risky as picking pockets. Besides, the job paid almost twice as much as the other one. We broke into tourists' cars mostly, or cars that we had good reason to believe carried enough goods. (Kiriamiti 1999a: 15) 
The assumption of new identities through the change of names - his other names are: Jack Wanjohi, Richard Mwangi or Jack Zollo - signals graduation from Kiriamiti's juvenile state of dabbling in "crimes of necessity" - which can also be understood as "learning the trade" - to a condition of crime as a "lifestyle" among young adults - a profession. The new state results into a situation in which law and order and the societal moral expectations are transgressed consciously. In other words, the widely accepted moral codes that determine individuals' relationship to both public and private property are substituted with self-constituted and individualized perceptions of morality that operate outside corporate morality and only take into consideration personal and private needs. Therefore, John Kiriamiti sheds his "common and normal identity" which would have bound him to the moral world in which he has grown and invests himself with a new identity. This newly acquired identity assures him of anonymity and strategic security within his new community of fellow criminals. Yet even within this group of fellow thieves Zollo discovers that "distrust" of each other pervades interpersonal relationships. Therefore, "If one got cash which the others were not aware of, he would keep it for himself. So after sharing what you all knew about, he would disappear until he had finished what he had" (Kiriamiti 1999a: 15).

Jack Zollo's integration into the underworld is rapid as he soon joins a group of armed gangsters who specialize in robbing banks. Three reasons convince him to join the gangsters. First, there is need to furnish his room and pay the rent. Secondly, although he fears the severity of the sentences meted out to apprehended criminals, he sees the system as "unjust" when a friend, Wanjau, is sentenced to serve fifteen years in prison on mistaken identity as a thief and two friends are sentenced to serve eleven years in prison and receive thirty-three strokes of the cane for attempting to break into a car (Kiriamiti 1999a: 19). Thirdly, the man who introduces Zollo to violent crime is highly educated and had had three different jobs, yet he had lost all of them. This mentor had decided to "try the other side of the law" (Kiriamiti 1999a: 21). Because of the temptation of big money involved, Zollo joins the gang and participates in a successful armed robbery of thirty three thousand Kenyan shillings in his first stint. He discovers that crime pays, and that there is an intricate web of relationships (networks) that ensure the success of several criminal endeavours in the society. For instance, he realizes that the first violent "money snatch" from a European man in which he participated involved the man's chauffeur, another man who hired out the gun to the gang, and a taxi driver whose car was used to escape from the scene of crime - an interconnected system of "small men". This group of disparate individuals operates in the understanding that there will be equitable distribution of the loot, depending on the order of risk that one runs during the robbery operations.

Jack Zollo learns the rules of the game and eventually emerges as a hard man, a tough gangster who is ready to employ violence to get what he wants as crime be- 
comes a key part of his life. Even his immediate family accepts his new status and lifestyle as a criminal. Occupational hazards such as occasional appearances in courts of law and being fined or jailed for a few weeks or months would hardly deter him from crime. Zollo's accomplices in crime are generally individuals who have lost their jobs for one reason or another. Joseph Thuku Kagwaci, a former bus driver who had been sacked for careless driving (Kiriamiti 1999a: 49), is an example. Zollo's notoriety as a tough and organized criminal soon makes him one of the "most wanted criminals" in Nairobi. When at last the law catches up with him and he faces the probability of a long jail term, he manages to trick his way out of police custody, escapes to Uganda and then Zaïre where he stays for a few years. When he returns to Kenya, he is arrested and jailed for twenty years in prison on appeal, together with corporal punishment of forty eight strokes of the cane.

John Kigia Kimani's story in Life and Times of a Bank Robber is similar to Jack Zollo's. Kimani is drawn to crime when life in the streets of Nairobi becomes unbearable with no money to buy food and a place to stay. Because he had to sleep in an unfinished building and also be on the lookout for policemen eager to arrest vagrants Kimani faces what he calls a "crisis" that he blames for having sowed the "germ of the criminal" in him (Kimani 1989: 23). He too progresses from selling stolen goods, to burglary and eventually to violent crime. After serving some time in a borstal school but from where he escapes, Kimani confesses that he was forced into crime by the need to have a wife (Kimani 1989: 32). Crime becomes a virtue for him with the passage of time, and he even rates car breaking as non-crime but house and shop breaking as crimes (Kimani 1989: 34). Ironically, it is after serving a prison sentence that Kimani graduates into a hardened criminal:

When I left prison, I was a proud student who had acquired some knowledge. But prison had not changed me from a criminal into a saint. The criminal mentality in me had not decreased at all even as I walked out of the prison gates. If anything, the prison had hardened me. I vowed that from then, I would not get involved in such small crimes as shop breaking but would take part only in big operations which would pay well. For a start, I learned to drive so that I could be well equipped for the future ahead of me. (Kimani 1989: 51)

Kimani, therefore, graduates from the world of common criminality to become a bigtime robber and gangster, just like Jack Zollo. As John Penny, Kimani lived the dream of "living among plenty" (Kimani 1989: 133). But all he ends up with is a "nightmare that [he] shall live with forever" (Kimani 1989: 133). Kimani spends a long period of time at Naivasha Prison, where he is subjected to all manners of suffering and torture including starvation. But he manages to study during the same period as well as write his book. His conclusion about the prison system in Kenya is that it is not a reformatory; rather, it hardens the criminals: 
Having spent a decade and a half in Kenyan prisons I learned that it is impossible to rehabilitate a human being through the prison system. The brutal treatment that we received in Naivasha Prison definitely would not have tamed me. It tended to turn us into animals rather than humanize us. My reformation was, therefore, not prompted by the joints check-ups or conversion to religion although I am a Christian. It came through a premeditated examination of conscience. (Kimani 1989: 132)

These stories of criminal escapades and daring daylight robberies that Zollo and Kimani narrate are manifestations of complex social dynamics which generate human desperation, conflict and struggle over economic resources and produce economies of violence that Achille Mbembe (2001) argues as characterizing the postcolony. Most importantly, though, they touch on the issue of the alienated socio-economic identity, which the writers seek to project through the voice of the "I" narrator. Zollo tells his story; Kimani too tells his story. In contrast, Meja and Maina are spoken for. One would conclude that Meja and Maina as minors are characteristically voiceless and therefore powerless, unlike Zollo and Kimani who claim their rights to determine their destinies, but through crime and violence.

Although John Kimani and John Kiriamiti condemn crime and violence, and suggest the reformation of criminals, what their stories are unable to deal with is the inevitability of the rise of younger (male) criminals to replace them. For instance John Kiriamiti's subsequent books, Son of Fate (1994) and The Sinister Trophy (1999) undo the reformist stance that he takes in My Life in Crime as it dwells on the emergence of young criminals from the pool of 'street children' in the cities of Kenya. The preponderance of male criminals in these texts parallels that of female characters in fiction that deals with prostitution - either act is a tool of choice by a social category to access means of livelihood.

\section{Concluding remarks}

There is a close connection between criminal activities by the youth and the socioeconomic structures of most societies. Violence and crime may be deployed by young men and women as strategies to access the networks of relationships and structures that determine the distribution of economic wealth. Incidences of crime may also be indicators of the emergence or presence of a different moral economy among urban poor or those social categories that are excluded from processes of (re)distributing material goods and benefits. Undoubtedly such a moral economy is parallel to and in conflict with the type of moral order that may be preferred by the state and its institutions of law and order. The struggle over resources that is depicted in the fiction of Meja Mwangi and John Kiriamiti may be fictive, but it closely mirrors the state of affairs in contemporary Kenya. The fictive characters, as actors and agents in a socio- 
economic context marked by inequalities, stand for such other individuals in real life. The division of individuals into socio-economic categories, as Bayart and Leys show, are based on networks in which political actors determine the (re)distribution of economic resources. Consequently, the urban poor - and even the rural poor who cannot live off land and consequently drift to urban centres hence swelling the numbers of the unemployed and underemployed people in towns and cities - whose incomes cannot afford them a decent life generally find themselves at the lowest tier in these networks or completely cut-off from them. The youth, who form a majority of these impoverished urban people, when confronted with a state of "arrested adolescence" or "postponed adulthood" find the alternative of crime for economic gains appealing (Pitts 2000: 11).

The state of a permanent uncertainty about the future, the improbability of ever getting employment, of ever satisfying one's immediate needs and of ever planning for the future causes a sense of hopelessness for many young men and women. In such a social context, a sense of injustice and inequity surrounds the lives of individuals such as Jack Zollo and John Kigia Kimani, who consciously decide to transgress and "operate on the other side of the law". In effect these deprived and underprivileged individuals imagine and construct their own world in which self-determined laws sanction their relationships to each other and with the rest of the society. The struggle over ownership of "Shanty Land" in Kill Me Quick, the use of aliases or fictitious identities by Jack Zollo and his co-criminals in My Life in Crime, the very styles of narration of personal experiences in Life and Times of a Bank Robber and in My Life in Crime, the confession to these crimes, are also instantiation of the alienated self. The individual characters in these fictions are excluded from enjoying or sharing in the material wealth of the Kenyan society by the "big men" and their networks. Hence in order for the "small men" to claim some of the "fruits of independence", denied them by their elders, they have to acquire disguises and alternative identities and also operate outside the authorized moral order and systems of law, order and justice because these institutions do not seem to serve the interests of all citizens. However, one notes that the same "elders" or the state may mobilize the youth to serve their own interests, as in intimidating opponents or some kind of "private army". This has been the case in many parts of Africa, and Kenya has had its own share of politically "organised youth gangs", as eloquently discussed by Peter Kagwanja (2005, 2006). In some cases youth violence (and even crime) may be expressions of an alienated identity or acts of rebellion against the older generation. Yet where leaders (and elders) have lost virtue and respect; and the claims to property and wealth are not mediated by institutionalized means of distributing these resources amongst the citizenry, crime and violence easily become attractive and often the preferred methods of accessing livelihood for marginalized social categories such as the youth. 


\section{Acknowledgement}

I am grateful to the anonymous reader who made comments on an earlier draft of this paper.

\section{Works cited}

Bayart, J. 1993. The State in Africa: The Politics of the Belly. London: Longman.

Berman, B. 1990. Control and Crisis in Colonial Kenya: the Dialectics of Domination. London: James Currey. Chabal, P. and Daloz, J. 1999. Africa Works: Disorder as Political Instrument. Oxford: James Currey.

De Boeck, P. and Honwana, A. 2005. Children and Youth in Africa: Agency, Identity and Place. In A. Honwana and P. De Boeck (eds.). Makers and Breakers: Children and Youth in Postcolonial Africa. Oxford: James Currey, 1-18.

Johansson, L. 1992. In the Shadow of Neocolonialism: A Study of Meja Mwangi's Novels, 1973 - 1990. Umea: University of Umea.

Kagwanja, P. 2006. "Power to Uhuru": Youth Identity and Generational Politics in Kenya's 2002 Elections. African Affairs 105(418): 51-75.

2005. Clash of Generations? Youth Identity, Violence and the Politics of Transition in Kenya, 1997-2002. In J. Abbink and I. van Kessel (eds.). Vanguards or Vandals: Youth, Politics and Conflict in Africa. Leiden: Brill.

Kehinde, A. 2004. Post-independence Disillusionment in Contemporary African Fiction: the Example of Meja Mwangi's Kill Me Quick. Nordic Journal of African Studies 13(2): 228-241.

Kimani, J. K. 1989. Life and Times of a Bank Robber. Nairobi: Spear Books.

Kiriamiti, J. 1994. Son of Fate. Nairobi: Spear Books. 1999a [1984]. My Life in Crime. Nairobi: Spear Books.

1999b. The Sinister Trophy. Nairobi: Spear Books.

Leys, C. 1978. [1975] Underdevelopment in Kenya: the Political Economy of Neocolonialism, 1964-1971. London: Heinemann Educational Books.

Lonsdale, J. and Berman, B. 1992. Unhappy Valley: Conflict in Kenya and Africa. London: James Currey.

Mbembe, A. 2001. On the Postcolony. Berkeley: University of California Press.

Mwangi, M. 2001 [1973]. Kill Me Quick. Nairobi: East African Educational Publishers.

Niebuhr, R. 2002. Young Africa: Policy Blueprint for a Continent of Youth. Johannesburg: Mandala Publishers.

Ochieng', W. R. 1996 [1995]. Independent Kenya's Development Strategies. In: B. A. Ogot and W. R. Ochieng' (eds.). Decolonization and Independence in Kenya, 1940 - 1993. Nairobi: East African Educational Books.

Pitts, J. 2001. The New Politics of Youth and Crime: Discipline or Solidarity? Houndmills, Basingstoke: Palgrave.

Throup, D. W. 1987. The Construction and Destruction of the Kenyatta state. In M. G. Schatzberg (ed.). The Political Economy of Kenya. New York: Praeger. 